\title{
Total mineralization of mixtures of Tartrazine, Ponceau SS and Direct Blue 71 azo dyes by solar photoelectro-Fenton in pre-pilot plant
}

\author{
Alexsandro Jhones dos Santos ${ }^{a}$, Ignasi Sirés ${ }^{b}$, Carlos A. Martínez-Huitle ${ }^{a}$,** Enric Brillas ${ }^{b}$ * \\ ${ }^{a}$ Laboratório de Eletroquímica Ambiental e Aplicada, Instituto de Química, Universidade Federal do Rio Grande do Norte, Lagoa Nova - CEP 59.072-900, Natal, RN, Brazil

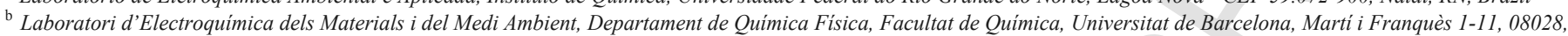 \\ Barcelona, Spain
}

\section{A R T I C LE INFO}

Article history:

Received 19 June 2018

Received in revised form 17 July 2018

Accepted 21 July 2018

Available online $\mathrm{xxx}$

Handling Editor:

Keywords:

Direct Blue 71

Ponceau SS

Solar photoelectro-Fenton

Tartrazine

Water treatment

\begin{abstract}
A B S T R A C T
Mixtures of monoazo Tartrazine, diazo Ponceau SS and triazo Direct Blue 71 dyes with $105 \mathrm{mg} \mathrm{L}^{-1}$ of total organic carbon (TOC) in $0.050 \mathrm{M} \mathrm{Na}_{2} \mathrm{SO}_{4}$ at $\mathrm{pH} 3.0$ have been treated by solar photoelectro-Fenton (SPEF). Experiments were carried out in a $2.5 \mathrm{~L}$ pre-pilot plant with a Pt/air-diffusion cell coupled to a solar planar photoreactor. Comparative trials were made by anodic oxidation with electrogenerated $\mathrm{H}_{2} \mathrm{O}_{2}\left(\mathrm{AO}-\mathrm{H}_{2} \mathrm{O}_{2}\right)$ and electro-Fenton (EF) to better understand the role of oxidizing agents. $\mathrm{AO}-\mathrm{H}_{2} \mathrm{O}_{2}$ gave poor degradation due to the low oxidation ability of ${ }^{\circ} \mathrm{OH}$ formed at the Pt anode and $\mathrm{H}_{2} \mathrm{O}_{2}$ nroduced at the cathode. Similar color removal was achieved in EF and SPEF because the main oxidant was ${ }^{\circ} \mathrm{OH}$ formed in the bulk from Fenton's reaction. EF yielded partial mineralization by formation of molecules with high stability against $\mathrm{OH}$. In contrast, these by-products were rapidly photolyzed under sunlight irradiation in SPEF, which was the most powerful treatment. Up to 8 linear final carboxylic acids were detected, along with the release of sulfate and ammonium ions. The effect of $\mathrm{Fe}^{2+}$ and azo dye concentrations, and current density over the SPEF performance was assessed. Total mineralization of azo dyes mixtures occurred when operating up to $105 \mathrm{mg} \mathrm{L}^{-1} \mathrm{TOC}$ with $0.50 \mathrm{mM} \mathrm{Fe}^{2+}$ at $100 \mathrm{~mA} \mathrm{~cm}^{-2}$.
\end{abstract}

\section{Introduction}

The presence of one or various azo $(-\mathrm{N}=\mathrm{N}-)$ bonds linked to aromatic rings with lateral anionic sulfonic groups confers to the azo dyes interesting industrial properties, including high stability and solubility in water, and yields characteristic colors depending on the aromatic systems involved (Robinson et al., 2001; Zollinger, 2003; Forgacs et al., 2004; Solís et al., 2012; Brillas and Martínez-Huitle, 2015). Azo dyes represent about $70-75 \%$ of the world dye production (Rajkumar and Kim, 2006) and are widely utilized in food and textile industries, which release large volumes of effluents loaded with mixtures containing up to $250 \mathrm{mg} \mathrm{L}^{-1}$ of such compounds. Dye wastewater presents major concerns when it is discharged into water bodies because its color and complex composition cause aesthetic problems, discouraging their downstream use (dos Santos et al., 2007; UNESCO, 2012; Brillas and Martínez-Huitle, 2015). Moreover, aquatic organisms can be affected by these chemicals due to their well-proven mutagenicity, carcinogenity and toxicity, along with the production of highly toxic by-products (Sharma et al., 2007; Ulson de Souza et al., 2007; Ghoneim et al., 2011). The persistence of dyes in the aquatic environment is associated to their large photostability and

\footnotetext{
* Corresponding author.

** Corresponding author.

Email addresses: carlosmh@quimica.ufrn.br (C.A. Martínez-Huitle); brillas@ub. edu (E. Brillas)
}

resistance to biodegradation, as well as to the ineffective decontamination by conventional treatments like filtration, adsorption and coagulation (Bhattacharya and Sanghi, 2003; dos Santos et al., 2007; Vilar et al., 2011; Verma et al., 2012; Brillas and Martínez-Huitle, 2015).

The effective degradation of azo dyes by in-situ generated hydroxyl radical $(\mathrm{OH})$ in advanced oxidation processes (AOPs) has been demonstrated (Forgacs et al., 2004; Anjaneyulu 1., 2005; Vilar et al., 2011; Khandegar and Saroha, 2013, Lllas and Martínez-Huitle, 2015). The high standard redox potential $\left(E^{\mathrm{o}}=2.80 \mathrm{~V} \mid \mathrm{SHE}\right.$ at $\left.\mathrm{pH} 0\right)$ of $\mathrm{OH}$ allows its non-selective reaction with most recalcitrant organic pollutants. Among the AOPs, great attention has been paid to the electrochemical AOPs (EAOPs) because of their simplicity along with high mineralization ability (Brillas et al., 2009; Panizza and Cerisola, 2009; Chaiyont et al., 2013; Oturan and Aaron, 2014; Sirés et al., 2014; Brillas and Martínez-Huitle, 2015; Moreira et al., 2017). Solar photoelectro-Fenton (SPEF) has recently emerged as the most viable EAOP thanks to the combined action of generated $\mathrm{OH}$ and solar photons to remove organics from wastewater (Ruiz et al., 2011; Salazar et al., 2012; Pérez et al., 2017; Steter et al., 2018). It is more potent than other ubiquitous EAOPs like anodic oxidation (AO) and electro-Fenton (EF). In AO, organics are destroyed by adsorbed $\mathrm{M}(\mathrm{OH})$ produced at the surface of an anode $\mathrm{M}$ from water oxidation at high current (Panizza and Cerisola, 2009):

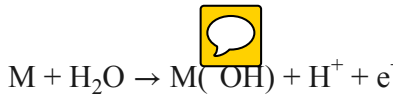


The best performance regarding the destruction of organics in $\mathrm{AO}$ is achieved with non-active boron-doped diamond (BDD) anodes (Santos et al., 2008; Bezerra Rocha et al., 2012; Sirés et al., 2014; Brillas and Martínez-Huitle, 2015), since they produce high quantities of physisorbed oxidant $\operatorname{BDD}(\mathrm{OH})$. In contrast, active anodes such as Pt possess much lower oxidation power because they accumulate small $\mathrm{Pt}(\mathrm{OH})$ concentrations as a result of its conversion to a superoxide $(\mathrm{PtO})$ with much weaker oxidation ability (Panizza and Cerisola, 2009; Sirés et al., 2014).

The use of a carbonaceous cathode in a one-compartment cell can favor the generation of other reactive oxygen species, like $\mathrm{H}_{2} \mathrm{O}_{2}$ from reaction (2), which can also contribute to the gradual oxidation of organics (Brillas et al., 2009; Oturan and Aaron, 2014; Sirés et al., 2014). The process is known as $\mathrm{AO}-\mathrm{H}_{2} \mathrm{O}_{2}$.

$$
\mathrm{O}_{2}+2 \mathrm{H}^{+}+2 \mathrm{e}^{-} \rightarrow \mathrm{H}_{2} \mathrm{O}_{2}
$$

In the EF process, a catalytic amount of $\mathrm{Fe}^{2+}$ is added to form homogeneous $\mathrm{OH}$ and $\mathrm{Fe}^{3+}$ upon reaction with electrogenerated $\mathrm{H}_{2} \mathrm{O}_{2}$, according to Fenton's reaction (3) (Brillas et al., 2009; Sirés et al., 2014). The $\mathrm{Fe}^{3+}$ refuction at the cathode regenerates $\mathrm{Fe}^{2+}$ to continuously produce $\mathrm{OH}$. Cathodes such as reticulated vitreous carbon (Coria et al., 2015; Ellouze et al., 2017), carbon felt (Dirany et al., 2012; El-Ghenymy et al., 2014), C-polymer air-diffusion (Olvera-Vargas et al., 2015; dos Santos et al., 2016; Galia et al., 2016) and BDD (Cruz-Rizo et al., 2017) have shown their great effectiveness for $\mathrm{H}_{2} \mathrm{O}_{2}$ production. The best anode for EF is RDD because of the superior oxidation ability of heterogeneous $\operatorname{BDD}\left({ }^{\circ} \mathrm{OH}\right)$ when it is combined with homogeneous $\mathrm{OH}$.

$$
\mathrm{H}_{2} \mathrm{O}_{2}+\mathrm{Fe}^{2+} \rightarrow \mathrm{Fe}^{3+}+\mathrm{OH}_{+}+\mathrm{OH}^{-}
$$

The SPEF process can be performed under EF conditions, with additional of the treated solution to sunlight (Solano et al., 2015; Thiam et al., 2015b) in order to develop a much more cost-effective method as compared to UVA photoelectro-Fenton (Thiam et al., 2015a; Garcias-Segura and Brillas, 2016). Apart from the oxidation with heterogeneous $\mathrm{M}\left({ }^{\circ} \mathrm{OH}\right)$ and homogeneous ${ }^{\circ} \mathrm{OH}$, the irradiated UV photons from sunlight favor: (i) the degradation of photoactive organics, (ii) the continuous regeneration of $\mathrm{Fe}^{2+}$, along with production of homogeneous $\mathrm{OH}$, from the photolysis of $\mathrm{Fe}$ (III) aquo-species according to reaction (4), and (iii) the photodecarboxylation of complexes of $\mathrm{Fe}(\mathrm{III})$ with some carboxylic acids via general reaction (5) (Sirés et al., 2014; Thiam et al., 2015b):

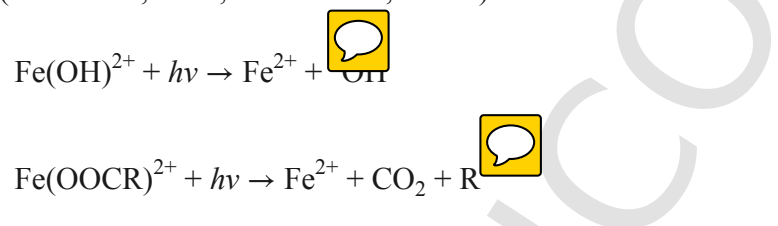

An advantage of SPEF is the need of less expensive anodes because of the crucial contribution of sunlight (Pérez et al., 2017). The beneficial use of SPEF for wastewater treatment has been checked for a reduced number of organics, but less is known about its degradation behavior over mixtures of azo dyes. This is an important issue in order to assess the viability of SPEF for the remediation of complex effluents containing azo dyes, whose different intermediates may react between them to difficult the mineralization process.

This work aims to investigate the decolorization and mineralization of a mixture of three azo dyes widely employed in the food and textile industries. The target compounds were the commercial sodium salts of monoazo Tartrazine $\left(\mathrm{C}_{16} \mathrm{H}_{9} \mathrm{~N}_{4} \mathrm{Na}_{3} \mathrm{O}_{9} \mathrm{~S}_{2}\right)$, the diazo Ponceau SS $\left(\mathrm{C}_{22} \mathrm{H}_{14} \mathrm{~N}_{4} \mathrm{Na}_{2} \mathrm{O}_{7} \mathrm{~S}_{2}\right)$ and the triazo Direct Blue 71 $\left(\mathrm{C}_{40} \mathrm{H}_{28} \mathrm{~N}_{7} \mathrm{Na}_{4} \mathrm{O}_{13} \mathrm{~S}_{4}\right)$ dyes (see Table $\mathrm{S} 1$ ). The assays were performed in $0.050 \mathrm{M} \mathrm{Na}_{2} \mathrm{SO}_{4}$ as supporting electrolyte at $\mathrm{pH} 3.0$ using a $2.5 \mathrm{~L}$ solar pre-pilot flow plant with an electrolytic cell containing an active $\mathrm{Pt}$ anode and an air-diffusion cathode, connected to a solar photoreactor. Comparative $\mathrm{AO}-\mathrm{H}_{2} \mathrm{O}_{2}$ and $\mathrm{EF}$ treatments were carried out to clarify the role of generated $\mathrm{M}\left({ }^{\circ} \mathrm{OH}\right)$ and ${ }^{\circ} \mathrm{OH}$, as well as the photolytic action of sunlight. The effect of the concentration of $\mathrm{Fe}^{2+}$ catalyst and azo dyes concentrations and current density $(j)$ on the decolorization and mineralization rates was examined. Final short-chain linear carboxylic acids were detected by high-performance liquid chromatography (HPLC) and the conversion of the initial $\mathrm{S}$ and $\mathrm{N}$ to inorganic ions is discussed.

\section{Materials and methods}

\subsection{Chemicals}

Tartrazine (68\% purity), Ponceau SS (77\% purity) and Direct Blue 71 (40\% purity) azo dyes were supplied by Sigma-Aldrich. The purity of each dye was confirmed by TOC analysis, since the rest of components were stabilizing salts. The supporting electrolyte was analytical grade $\mathrm{Na}_{2} \mathrm{SO}_{4}$ purchased from Prolabo. The catalyst used for EF and SPEF was analytical grade $\mathrm{FeSO}_{4} \cdot 7 \mathrm{H}_{2} \mathrm{O}$ purchased from Fluka. $\mathrm{H}_{2} \mathrm{SO}_{4}$ (98\% purity) supplied by Merck was used to adjust the solution $\mathrm{pH}$ to 3.0. All reagents for analysis were of HPLC or analytical grade purchased from Merck and Panreac. Deionized water was used to prepare the synthetic solutions.

\subsection{Electrochemical advanced oxidation treatments}

All the trials were made in a solar pre-pilot flow plant schematized in earlier work (Flox et al., 2007). A volume of $2.5 \mathrm{~L}$ of dye mixture was recirculated from the reservoir, thanks to a centrifugal pump, to the electrochemical cell coupled to a solar planar photoreactor. A flowmeter was used to regulate the liquid flow rate to $180 \mathrm{~L} \mathrm{~h}^{-1}$ and two heat exchangers allowed operating at $35^{\circ} \mathrm{C}$, with the photoreactor exposed to direct sunlight irradiation. The cell was a one-compartment filter-press reactor equipped with two parallel electrodes of $20 \mathrm{~cm}^{2}$ area in contact with the solution, separated $1.2 \mathrm{~cm}$. The anode was a Pt plate supplied by SEMPSA (Barcelona, Spain) and the cathode was a carbon-polytetrafluoroethylene (PTFE) air-diffusion electrode supplied by Sainergy Fuel Cell (Chennai, India). The outer face of the cathode was in contact with a gas chamber filled with atmospheric air at $4.5 \mathrm{Lh}^{-1}$ to continuously produce $\mathrm{H}_{2} \mathrm{O}_{2}$. The photoreactor was a polycarbonate box $(24.0 \mathrm{~cm} \times 24.0 \mathrm{~cm} \times 2.5 \mathrm{~cm}, 600 \mathrm{~mL}$ of irradiated volume), with a mirror at the bottom and tilted $41^{\circ}$ (latitude of Barcelona). An Agilent 6552A DC power supply provided constant $j$, directly displaying the instantaneous cell voltage. The SPEF experiments lasted $300 \mathrm{~min}$ and were made in clear and sunny days of the summer of 2017 , with an average UV power of $33.7 \mathrm{Wm}^{-2}$, determined with a Kipp \& Zonen CUV 5 radiometer. Analogous AO- $\mathrm{H}_{2} \mathrm{O}_{2}$ and $\mathrm{EF}$ tests were carried out by covering the system with an opaque cloth.

\subsection{Equipment and analysis}

The $\mathrm{pH}$ of all solutions was determined with a GLP $22 \mathrm{pH}-\mathrm{me}$ ter from Crison. Samples for analysis were immediately adjusted to 
$\mathrm{pH}=8.0$ to stop the degradation process and filtered with $0.45 \mu \mathrm{m}$ PTFE filters from Whatman.

The color loss was determined from the absorbance decay at $\lambda_{\max }=515 \mathrm{~nm}$ (see the UV/vis spectrum of the mixture in Fig. SM-1), using a Shimadzu $1800 \mathrm{UV} /$ Vis spectrophotometer. The percentage of color removal for a treated solution with absorbance $A$ at electrolysis time $t$ starting from an initial absorbance $A_{0}$ was calculated from Eq. (6) (Ruiz et al., 2011):

$$
\% \text { Color removal }=\frac{A_{0}-A}{A_{0}} 100
$$

The TOC of the solutions was measured with a Shimadzu VCSN TOC analyser using the non-purgeable organic carbon method. $50 \mu \mathrm{L}$ aliquots were injected into the analyser to obtain values with $\pm 1 \%$ reproducibility. Decolorization and TOC measurements were replicated and average values (with error bars in figures) are reported.

From the TOC abatement $\left(\triangle(\mathrm{TOC})_{\text {exp }}\right)$ at electrolysis time $t$ (in h) of a given assay, the mineralization current efficiency (MCE, in \%) was estimated from Eq. (7) (Murillo-Sierra et al., 2018):

$$
\% \mathrm{MCE}=\frac{n_{\text {mean }} F V \Delta(\mathrm{TOC})}{4.32 \times 10^{7} m_{\text {mean }}} \bigoplus
$$

where $n_{\text {mean }}$ and $m_{\text {mean }}$ denote the mean number of electrons for the mineralization process and the average number of $\mathrm{C}$ atoms in the mixture, respectively, $F$ is the Faraday constant, $V$ is the solution volume (in L), $4.32 \times 10^{7}$ is a conversion factor $\left(3600 \mathrm{~s} \mathrm{~h}^{-1} \times 12,000 \mathrm{mgC}\right.$ $\mathrm{mol}^{-1}$ ) and $I$ is the applied current (in A). The $n_{\text {mean }}$ and $m_{\text {mean }}$ values depend on the composition of the treated mixture and the mineralization reaction of each dye, as discussed below.

The specific energy consumption per unit TOC mass $\left(\mathrm{EC}_{\mathrm{TOC}}\right)$ for the trials was determined from the average cell voltage $E_{\text {cell }}$ (in V) according to Eq. (8) (Flox et al., 2007; Ruiz et al., 2011):

$$
\mathrm{EC}_{\mathrm{TOC}}\left(\mathrm{kWh}\left(\mathrm{gTOC}^{-1}\right)=\frac{E_{\mathrm{cell}} I t}{V \Delta(\mathrm{TOC})_{\exp }}\right.
$$

Generated short-chain linear aliphatic carboxylic acids were identified and quantified by ion-exclusion $\mathrm{HPLC}, \mathrm{NH}_{4}^{+}$concentration was determined from the standard phenate method. $\mathrm{SO}_{4}{ }^{2-}$ and $\mathrm{NO}_{3}{ }^{-}$concentrations were obtained by ion chromatography, using the apparatus and procedures reported earlier (Coria et al., 2018; dos Santos et al., 2018).

\section{Results and discussion}

\subsection{Comparative treatment by electrochemical advanced oxidation processes}

Solutions of $2.5 \mathrm{~L}$ of $0.136 \mathrm{mM}$ Tartrazine $+0.154 \mathrm{mM}$ Ponceau $\mathrm{SS}+0.080 \mathrm{mM}$ Direct Blue 71 , corresponding to $105 \mathrm{mg} \mathrm{L}^{-1} \mathrm{TOC}$, were prepared in $0.050 \mathrm{M} \mathrm{Na}_{2} \mathrm{SO}_{4}$ at $\mathrm{pH} 3.0$ (i.e., the optimum value for E SPEF (Brillas et al., 2009; Brillas and Martínez-Huitle, $2015) \sim$ and SPEF were carried out in the presence of $0.50 \mathrm{mM}$
$\mathrm{Fe}^{2+}$ as catalyst. The temperature was always kept at $35^{\circ} \mathrm{C}$, which is important for systems exposed to sunlight. A first set of trials was carried out by $\mathrm{AO}-\mathrm{H}_{2} \mathrm{O}_{2}, \mathrm{EF}$ and SPEF under comparable conditions by applying a $j=100 \mathrm{~mA} \mathrm{~cm}^{-2}$ for $300 \mathrm{~min}$. The solution $\mathrm{pH}$ did not vary substantially along the electrolysis.

Fig. 1a shows a slow decolorization of the mixture by $\mathrm{AO}-\mathrm{H}_{2} \mathrm{O}_{2}$, only attaining $26.0 \%$ of color removal after $100 \mathrm{~min}$. This surgests that the attack of the generated oxidizing species $\left(\mathrm{H}_{2} \mathrm{O}_{2}\right.$ and $\left.\mathrm{Pt}(\mathrm{OH})\right)$ on the azo dyes was mild. In contrast, Fig. 1a highlights that the generation of homogeneous ${ }^{\circ} \mathrm{OH}$ from Fenton's reaction (3) in EF and SPEF caused a great acceleration of decolorization, reaching 98.0\% and $99.8 \%$ at $100 \mathrm{~min}$, respectively. The slight superiority of SPEF over EF can be attributed to the additional $\mathrm{OH}$ production induced by photolytic reaction (4). The inset of Fig. 1a depicts the excellent pseudo-first-order linear correlations found for the time course of the absorbance decays. This behavior presupposes that a constant amount of generated hydroxyl radicals $(\mathrm{Pt}(\mathrm{OH})$ and $\mathrm{OH})$ degrades each azo dye. The slope corresponds to the apparent rate constant for decolorization $\left(k_{\mathrm{dec}}\right)$. The values obtained for the trials are collected in
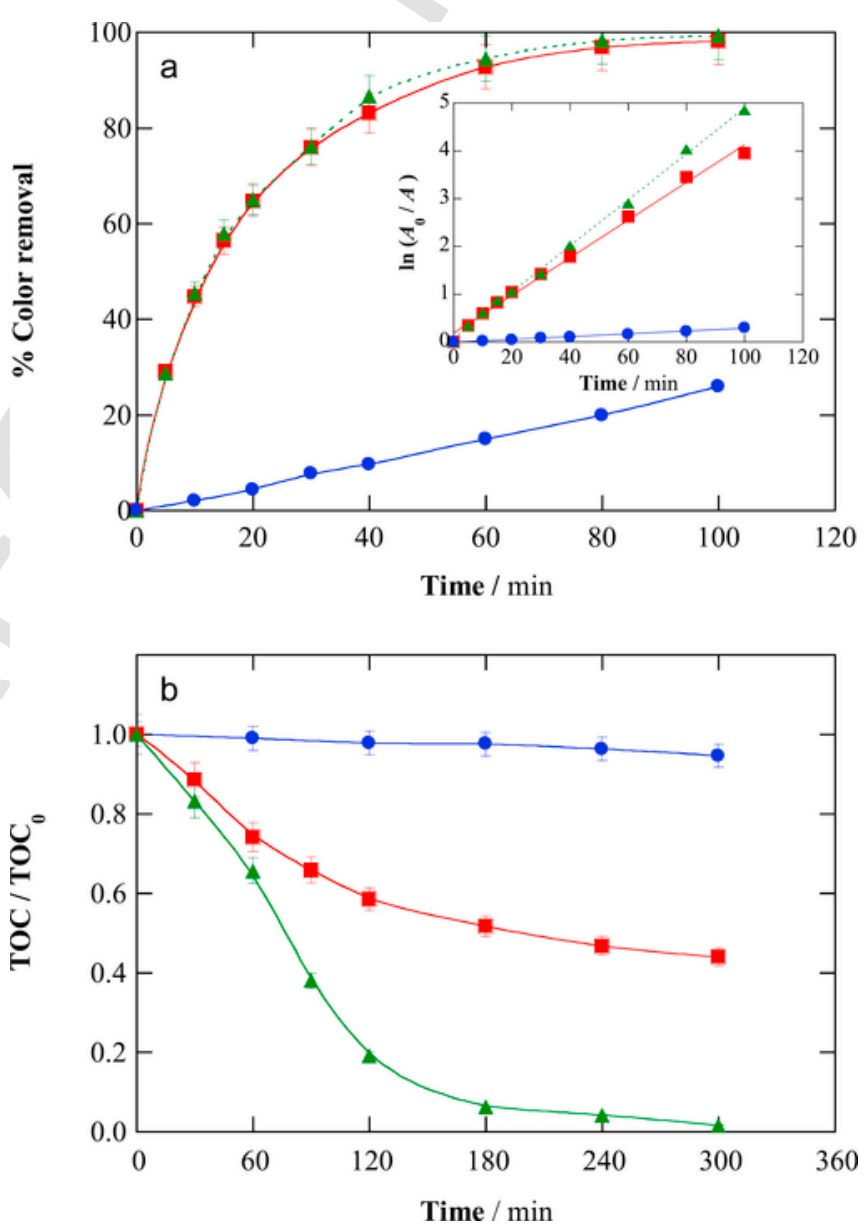

Fig. 1. (a) Percentage of color removal at $\lambda \max =515 \mathrm{~nm}$ and (b) normalized TOC removal with electrolysis time for the treatment of $2.5 \mathrm{~L}$ of a mixture of $0.136 \mathrm{mM}$ Tartrazine $+0.154 \mathrm{mM}$ Ponceau SS $+0.080 \mathrm{mM}$ Direct Blue $71(105 \mathrm{mg} \mathrm{L}-1 \mathrm{TOC})$ in $0.050 \mathrm{M} \mathrm{Na} 2 \mathrm{SO} 4$ at $\mathrm{pH} 3.0$ using a pre-pilot flow plant with a $\mathrm{Pt} /$ air-diffusion press cell of $20 \mathrm{~cm} 2$ electrode area coupled to a solar planar photoreactor of $600 \mathrm{~mL}$ of irradiation volume, at current density $(\mathrm{j})=100 \mathrm{~mA} \mathrm{~cm}-2$, liquid flow rate of $180 \mathrm{~L} \mathrm{~h}-1$ and $35^{\circ} \mathrm{C}$. Method: (๑) anodic oxidation with electrogenerated $\mathrm{H} 2 \mathrm{O} 2(\mathrm{AO}-\mathrm{H} 2 \mathrm{O} 2)$, (口) electro-Fenton (EF) with $0.50 \mathrm{mM} \mathrm{Fe} 2+$ and $(\mathbf{\Delta})$ solar photoelectro-Fenton (SPEF) with $0.50 \mathrm{mM} \mathrm{Fe} 2+$. (For interpretation of the references to color in this figure legend, the reader is referred to the Web version of this article.) 
Table 1, along with the good $R$-squared obtained. As can be seen, the $k_{\mathrm{dec}}$-value for SPEF $\left(0.048 \mathrm{~min}^{-1}\right)$ was 1.23 -fold higher than that found in $\mathrm{EF}\left(0.039 \mathrm{~min}^{-1}\right)$, whereas the latter was 13-fold higher than that obtained in $\mathrm{AO}-\mathrm{H}_{2} \mathrm{O}_{2}$. This corroborates the higher oxidation power of $\mathrm{OH}$ compared to $\mathrm{Pt}(\mathrm{OH})$ to destroy the azo dye molecules.

Fig. $1 b$ illustrates a very different behavior for normalized TOC removals under the above conditions, with mineralization being clearly upgraded in the sequence: AO- $\mathrm{H}_{2} \mathrm{O}_{2}<\mathrm{EF}<\mathrm{SPEF}$. Table 1 shows that the TOC decay attained using $\mathrm{AO}-\mathrm{H}_{2} \mathrm{O}_{2}$ was as low as $5.4 \%$, as expected from the low oxidation ability of $\mathrm{Pt}\left({ }^{\circ} \mathrm{OH}\right)$ (Panizza and Cerisola, 2009). A higher TOC decay was achieved by EF (56.0\%), whereas SPEF led to overall mineralization ( $\sim 99 \%$ TOC removal). This means that a large amount of intermediates originated in EF were converted to $\mathrm{CO}_{2}$ upon action of ${ }^{\circ} \mathrm{OH}$ generated from Fenton's reaction (3). The photolytic destruction of photoactive organics hardly degraded by hydroxyl radicals, like Fe(III)-carboxylate complexes (Brillas et al., 2009; Salazar et al., 2012; Moreira et al., 2017; Pérez et al., 2017; Steter et al., 2018), under UV irradiation explains the large effectiveness of SPEF to reach complete mineralization.

\subsection{Evolution of short-chain linear carboxylic acids and inorganic ions released in SPEF}

The azo dye mixture treated by SPEF was analyzed by ion-exclusion HPLC, allowing the detection of eight generated carboxylic acids like tartronic, tartaric, malic, succinic, acetic, oxalic, formic and oxamic. The five former acids arise from the cleavage and ring opening of the aromatic rings, which are independently transformed into oxalic and formic acids (Brillas et al., 2009; Sirés et al., 2014). Oxamic acid is formed from $\mathrm{N}$-intermediates. Oxalic, formic and oxamic acids are final by-products that can be directly mineralized (Sirés et al., 2014; Solano et al., 2015; Thiam et al., 2015a, 2015b; Garcia-Segura and Brillas, 2016).

Under the SPEF conditions tested, a large accumulation of $\mathrm{Fe}^{3+}$ formed from Fenton's reaction (3) is expected (Flox et al., 2007; Brillas et al., 2009). Thus, all carboxylic acids form complexes with $\mathrm{Fe}(\mathrm{III})$ that can be easily photolyzed from reaction (5). Fig. 2a illustrates maximum contents of $13.3,15.8,19.5$ and $69.8 \mathrm{mg} \mathrm{L}^{-1}$ for formic, tartronic, oxamic and oxalic acids, respectively, whereas Fig. $2 \mathrm{~b}$ shows smaller maximum values of $1.0,7.3,7.9$ and $8.4 \mathrm{mgL}^{-1}$ for succinic, acetic, tartaric and malic acids, respectively. Both figures

\section{Table 1}

Apparent rate constant for decolorization, with the corresponding $R$-squared, and percentage of TOC removal, mineralization current efficiency and specific energy consumption per unit TOC mass after $300 \mathrm{~min}$ of treatment of $2.5 \mathrm{~L}$ of Tartrazine + Ponceau SS + Direct Blue 71 mixtures in $0.050 \mathrm{M} \mathrm{Na}_{2} \mathrm{SO}_{4}$ at $\mathrm{pH} 3.0$ and $35^{\circ} \mathrm{C}$. A pre-pilot flow plant with a Pt/air-diffusion cell was used for $\mathrm{AO}-\mathrm{H}_{2} \mathrm{O}_{2}$ and $\mathrm{EF}$, being coupled to a planar photoreactor in SPEF.

\begin{tabular}{|c|c|c|c|c|c|c|c|c|}
\hline Method & $\begin{array}{l}\mathrm{TOC}_{0} \\
(\mathrm{mg} \\
\left.\mathrm{L}^{-1}\right)\end{array}$ & $\left.\mathrm{cm}^{-2}\right)$ & $\begin{array}{l}{\left[\mathrm{Fe}^{2+}\right]_{0}} \\
(\mathrm{mM})\end{array}$ & $\left(\min ^{-1}\right)$ & & $\begin{array}{l}\% \mathrm{TOC} \\
\text { removal }\end{array}$ & $\begin{array}{l}\% \\
\text { MCE }\end{array}$ & $\begin{array}{l}\mathrm{EC}_{\mathrm{TOC}} \\
(\mathrm{kWh}(\mathrm{g} \\
\left.\mathrm{TOC}^{-1}\right)\end{array}$ \\
\hline $\begin{array}{l}\mathrm{AO}- \\
\mathrm{H}_{2} \mathrm{O}_{2}\end{array}$ & 105 & 100 & - & $3.0 \times 10$ & 0.994 & 5.4 & 1.3 & 11.99 \\
\hline $\mathrm{EF}$ & 105 & 100 & 0.50 & 0.039 & 0.994 & 56.0 & 13.2 & 1.16 \\
\hline \multirow[t]{7}{*}{ SPEF } & 52 & 100 & 0.50 & 0.079 & 0.998 & 99.0 & 11.4 & 1.34 \\
\hline & 105 & 50 & 0.50 & 0.019 & 0.990 & 89.2 & 42.1 & 0.21 \\
\hline & 105 & 100 & 0.25 & 0.028 & 0.987 & 86.4 & 20.4 & 0.75 \\
\hline & 105 & 100 & 0.50 & 0.048 & 0.998 & 98.8 & 23.2 & 0.66 \\
\hline & 105 & 100 & 2.00 & 0.023 & 0.992 & 76.4 & 18.0 & 0.85 \\
\hline & 105 & 150 & 0.50 & 0.064 & 0.990 & 98.5 & 15.4 & 1.34 \\
\hline & 157 & 100 & 0.50 & 0.029 & 0.996 & 89.7 & 31.7 & 0.48 \\
\hline
\end{tabular}

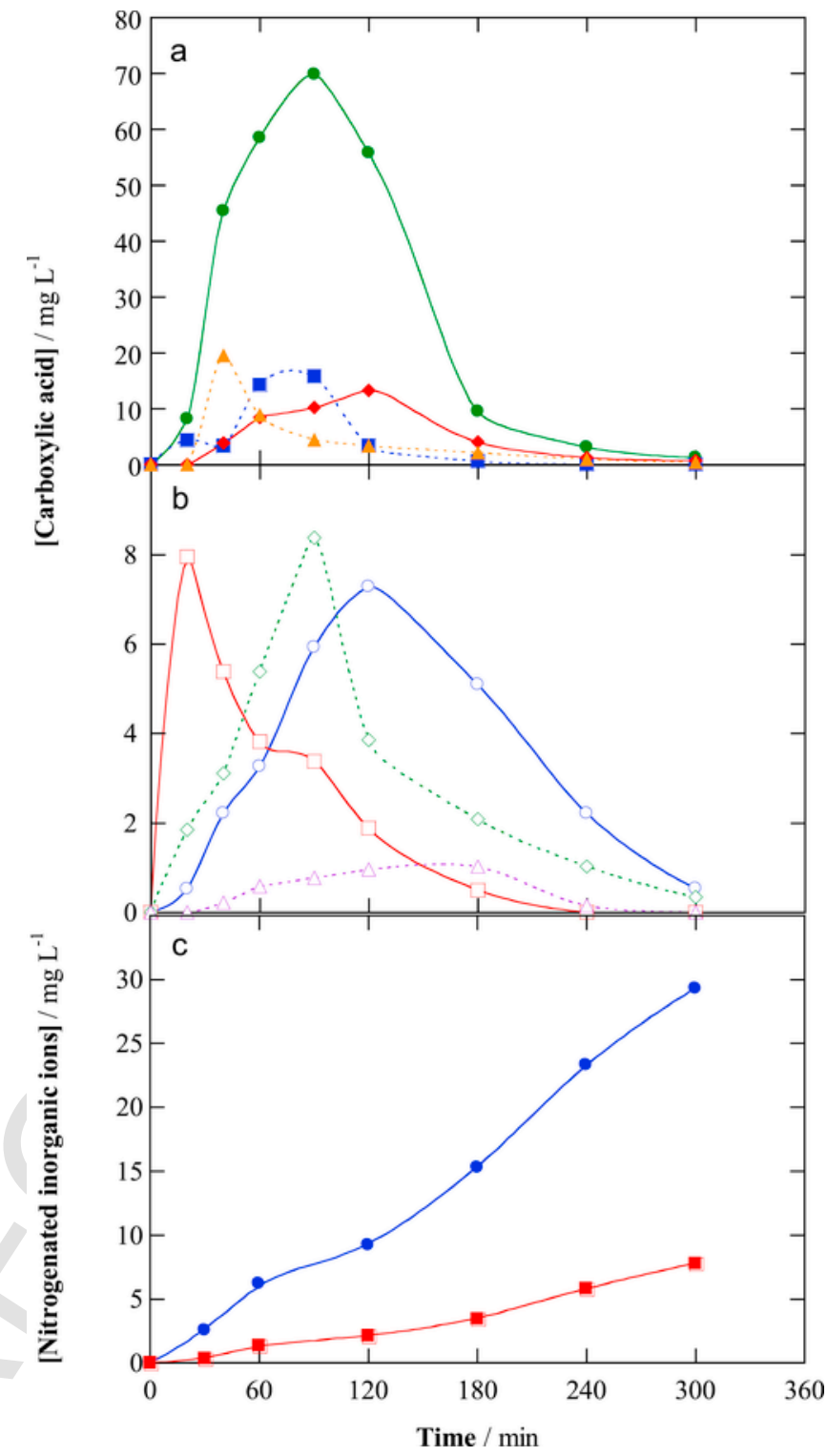

Fig. 2. Evolution of the concentration of (a) (๑) oxalic, (ם) tartronic, ( $\bullet$ ) formic and (A ic acids, (b) $(\bigcirc)$ acetic, $(\square)$ tartaric, $(\diamond)$ malic and $(\triangle)$ succinic acids, and (c) $(\bullet)$ and ( $\square$ ) NO3- ions, detected during the same SPEF trial of Fig. 1.

evidence that all final acids were completely removed at $300 \mathrm{~min}$ of SPEF. This fact, related to the large photolytic power of the UV photons from sunlight, explains the overall mineralization achieved in SPEF.

The released inorganic ions during the above SPEF treatment were also determined. A final $\mathrm{SO}_{4}{ }^{2-}$ concentration of $164.8 \mathrm{mg} \mathrm{L}^{-1}$ was obtained, accounting for the release of $99.9 \%$ of the initial $\mathrm{S}$ $\left(55.0 \mathrm{mgL}^{-1}\right)$. Fig. $2 \mathrm{c}$ shows the continuous formation of $\mathrm{NO}_{3}^{-}$and $\mathrm{NH}_{4}^{+}$ions during the trial, attaining 7.8 and $29.3 \mathrm{mgL}^{-1}$. This corresponds to $2.7 \%$ and $35.0 \%$ of the initial $\mathrm{N}$ content $\left(65.1 \mathrm{mgL}^{-1}\right)$, respectively. No other nitrogenated ions like $\mathrm{NO}_{2}^{-}$were detected. Since overall mineralization was reached, these results suggest that about $62 \%$ of the initial $\mathrm{N}$ was lost from the solution in the form of $\mathrm{N}_{2}$ and $\mathrm{N}_{\mathrm{x}} \mathrm{O}_{\mathrm{y}}$ species, as previously reported for other $N$-compounds, including azo (Ruiz et al., 2011; Thiam et al., 2015a, 2015b; dos Santos et al., 20, Pérez et al., 2017). 


\subsection{Mineralization current efficiency and energy consumption}

The above study allows concluding that the azo dye mixture can be completely mineralized to $\mathrm{CO}_{2}$ by SPEF, with release of $\mathrm{SO}_{4}{ }^{2-}$ and $\mathrm{NH}_{4}{ }^{+}$as the predominant nitrogenated ion. The total mineralization reactions of the anionic forms of Tartrazine, Ponceau SS and Direct Blue 71 can be written as follows:

$$
\begin{aligned}
& \mathrm{C}_{16} \mathrm{H}_{9} \mathrm{~N}_{4} \mathrm{O}_{9} \mathrm{~S}_{2}{ }^{3-}+31 \mathrm{H}_{2} \mathrm{O} \rightarrow 16 \mathrm{CO}_{2}+2 \mathrm{SO}_{4}{ }^{2-}+4 \mathrm{NH}_{4}{ }^{+}+ \\
& 55 \mathrm{H}^{+}+58 \mathrm{e}^{-}
\end{aligned}
$$

$$
\begin{aligned}
& \mathrm{C}_{22} \mathrm{H}_{14} \mathrm{~N}_{4} \mathrm{O}_{7} \mathrm{~S}_{2}{ }^{2-}+45 \mathrm{H}_{2} \mathrm{O} \rightarrow \\
& 22 \mathrm{CO}_{2}+2 \mathrm{SO}_{4}{ }^{2-}+4 \mathrm{NH}_{4}^{+}+88 \mathrm{H}^{+}+90 \mathrm{e}^{-}
\end{aligned}
$$

$\mathrm{C}_{40} \mathrm{H}_{28} \mathrm{~N}_{7} \mathrm{O}_{13} \mathrm{~S}_{4}{ }^{4-}+83 \mathrm{H}_{2} \mathrm{O} \rightarrow$

$40 \mathrm{CO}_{2}+4 \mathrm{SO}_{4}^{2-}+7 \mathrm{NH}_{4}^{+}+166 \mathrm{H}^{+}+169 \mathrm{e}^{-}$

From these equations and considering a molar fraction of 0.367 , 0.416 and 0.217 for Tartrazine, Ponceau SS and Direct Blue 71, respectively, an $n_{\text {mean }}=95.40$ and $m_{\text {mean }}=23.70$ can be calculated, thus being possible to estimate the MCE values from Eq. (7). Fig. SM-2a depicts the MCE profiles obtained for the above $\mathrm{AO}-\mathrm{H}_{2} \mathrm{O}_{2}, \mathrm{EF}$ and SPEF treatments of the azo dye mixture, and the values found at $300 \mathrm{~min}$ are given in Table 1. As expected, MCE values as low as $1.0-1.2 \%$ were found for $\mathrm{AO}-\mathrm{H}_{2} \mathrm{O}_{2}$ due to its lower oxidation power. A great upgrade of MCE can be observed in EF, further enhanced in SPEF. In these cases, maximum current efficiencies of $30.5 \%$ at $60 \mathrm{~min}$ and $48.8 \%$ at $90 \mathrm{~min}$, respectively, were obtained. After those electrolysis times, a dramatic decay in MCE occurred down to $13.2 \%$ and $23.2 \%$ at the end of such treatments (see Table 1). This trend is typical of EAOPs, being related to the progressive consumption of organic load and the generation of by-products that are more hardly oxidizable (Brillas et al., 2009; Panizza and Cerisola, 2009). For example, $\mathrm{Fe}(\mathrm{III})$ complexes of the short-chain linear carboxylic acids mentioned above.

Fig. SM-2b highlights the course of $\mathrm{EC}_{\mathrm{TOC}}$ calculated from Eq. (8) for the same assays. The low mineralization degree achieved in AO- $\mathrm{H}_{2} \mathrm{O}_{2}$ justifies the very high $\mathrm{EC}_{\mathrm{TOC}}$ values determined, up to $15.8 \mathrm{kWh}(\mathrm{g} \mathrm{TOC})^{-1}$. Much lower consumptions were needed in EF and SPEF, changing from 0.50 to $1.16 \mathrm{kWh}(\mathrm{g} \mathrm{TOC})^{-1}$ and from 0.31 to $0.56 \mathrm{kWh}(\mathrm{g} \text { TOC })^{-1}$, respectively. The combined action of $\mathrm{Pt}(\mathrm{OH}), \mathrm{OH}$ and $\mathrm{UV}$ radiation favors the overall mineralization of the azo dye mixture, with concomitant maximum MCE and minimum $\mathrm{EC}_{\mathrm{TOC}}$ values.

\subsection{Effect of experimental variables on the performance of SPEF treatment}

Once the superiority of SPEF over the other EAOPs tested for the decolorization and mineralization of the azo dyes mixture was verified, the influence of experimental parameters such as $\mathrm{Fe}^{2+}$ concentration, applied $j$ and pollutant concentration on its performance was examined in order to find the best operation conditions. The $\mathrm{Fe}^{2+}$ concentration affects the rate of Fenton's reaction (3) and, consequently, the production of oxidant ${ }^{\circ} \mathrm{OH}$ in the bulk. Its effect was assessed between 0.25 and $2.00 \mathrm{mM}$, being tested for a mixture containing $0.136 \mathrm{mM}$ Tartrazine $+0.154 \mathrm{mM}$ Ponceau SS $+0.080 \mathrm{mM}$ Direct Blue $71\left(\mathrm{TOC}_{0}=105 \mathrm{mg} \mathrm{L}^{-1}\right)$ at $\mathrm{pH} 3.0$ and $j=100 \mathrm{mAcm}^{-2}$. Fig. $3 \mathrm{a}$ and $\mathrm{b}$ illustrate the comparative percentage of color removal
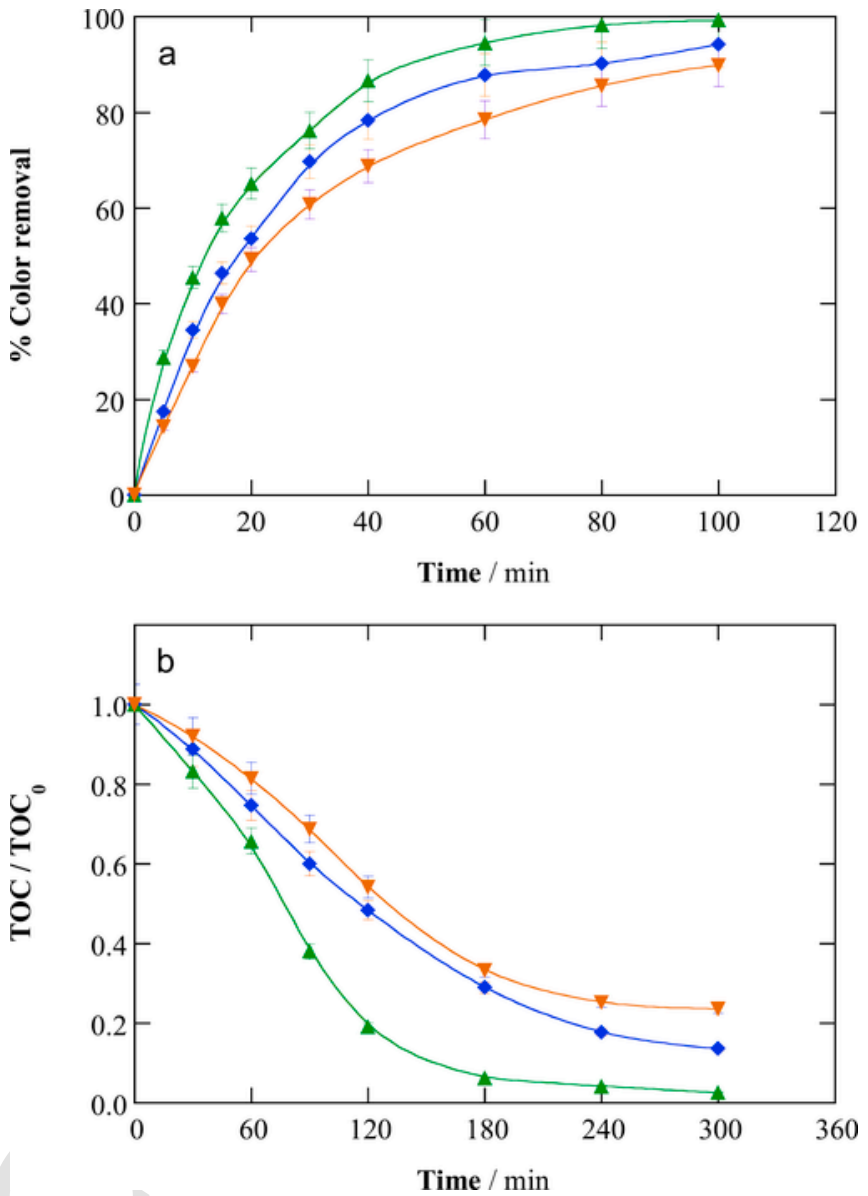

Fig. 3. Effect of $\mathrm{Fe} 2+$ concentration on (a) percentage of color removal and (b) normalized TOC abatement with electrolysis time for the SPEF treatment of the mixture of azo dyes of Fig. 1 using a solar pre-pilot flow plant under the same experimental conditions, except $[\mathrm{Fe} 2+] 0:(\bullet) 0.25 \mathrm{mM},(\Delta) 0.50 \mathrm{mM}$ and $(\boldsymbol{\nabla}) 2.00 \mathrm{mM}$. (For interpretation of the references to color in this figure legend, the reader is referred to the Web version of this article.)

and normalized TOC decay profiles for these tests, respectively. A great acceleration in the decolorization of the mixture can be seen when changing from 0.25 to $0.50 \mathrm{mM} \mathrm{Fe} e^{2+}$, but further increase to $2.00 \mathrm{mM}$ yielded a slower color loss, even worse than that obtained at $0.25 \mathrm{mM}$. This trend can also be deduced from the $k_{\mathrm{dec}}$-values obtained from the kinetic analysis performed for the absorbance decay and presented in the inset of Fig. 3a. Table 1 reveals that the $k_{\mathrm{dec}}$-value at $0.50 \mathrm{mM} \mathrm{Fe}{ }^{2+}$ was 1.71 -fold and 2.09 -fold higher than at 0.25 and $2.00 \mathrm{mM}$, respectively. This means that the largest generation of $\mathrm{OH}$ from Fenton's reaction (3) was achieved at $0.50 \mathrm{mM}$ $\mathrm{Fe}^{2+}$. This concentration was also optimal for TOC removal, as can be seen in Fig. 3b, since only partial mineralization $(<87 \%$ TOC reduction) was reached at 0.25 and $2.00 \mathrm{mM} \mathrm{Fe}^{2+}$ (cee Table 1). This behavior confirms the positive oxidation power of ${ }^{\circ} \mathrm{OH}$ during SPEF. The enhancement of this process from 0.25 to $0.50 \mathrm{mM} \mathrm{Fe}^{2+}$ can be accounted for by the acceleration of Fenton's reaction (3) due to the presence of higher concentration of catalyst. The opposite tendency observed when $\mathrm{Fe}^{2+}$ content rose from 0.50 to $2.00 \mathrm{mM}$ can be related to the consumption of a large amount of $\mathrm{OH}$ by the excess of catalyst added, as shown in reaction (12) (Brillas et al., 2009; Ruiz et al., 2011). Accordingly, the highest $\mathrm{MCE}$ and smallest $\mathrm{EC}_{\mathrm{TOC}}$ values 
resulted for the optimum system with $0.50 \mathrm{mM} \mathrm{Fe}^{2+}$ (see Table 1).

$$
\mathrm{Fe}^{2+}+\mathrm{O}_{\mathrm{OHI}} \rightarrow \mathrm{Fe}^{3+}+\mathrm{OH}^{-}
$$

The effect of $j$ on SPEF process was assessed in the range $50-150 \mathrm{~mA} \mathrm{~cm}^{-2}$ for the mixture composed of $0.136 \mathrm{mM}$ Tartrazine $+0.154 \mathrm{mM}$ Ponceau SS $+0.080 \mathrm{mM}$ Direct Blue 71 $\left(\mathrm{TOC}_{0}=105 \mathrm{mg} \mathrm{L}^{-1}\right)$ at $\mathrm{pH} 3.0$, in the presence of $0.50 \mathrm{mM} \mathrm{Fe}^{2+}$. It is expected that an increase in $j$ accelerates all the electrode reactions, leading to higher amount of $\mathrm{Pt}(\mathrm{OH})$ from reaction (1) and $\mathrm{H}_{2} \mathrm{O}_{2}$ from reaction (2), with the consequent enhancement of the $\mathrm{OH}$ production from Fenton's reaction (3) (Ruiz et al., 2011; Salazar et al., 2012; Pérez et al., 2017). Under these conditions, the destruction of organics by such hydroxyl radicals is upgraded. Hence, photoactive intermediates are more rapidly formed and, in turn, they can be more quickly photolyzed under sunlight irradiation. This tendency can be observed in Fig. $4 \mathrm{a}$ and $\mathrm{b}$ for the decolorization and mineralization of the mixture, respectively. Only $86.0 \%$ of color disappeared after 100 minat $j=50 \mathrm{~mA} \mathrm{~cm}^{-2}$, in contrast to its total disappearance at higher $i$ values of 100 and $150 \mathrm{~mA} \mathrm{~cm}^{-2}$, due to the lower generation of $\mathrm{Pt}(\mathrm{OH})$ and $\mathrm{OH}$. This is also reflected in the $k_{\mathrm{dec}}$-values obtained from the pseudo-first-order kinetic analysis shown in the inset of Fig. 4a, which rose 2.5 -fold at $j=100 \mathrm{~mA} \mathrm{~cm}^{-2}$ and 3.4-fold at
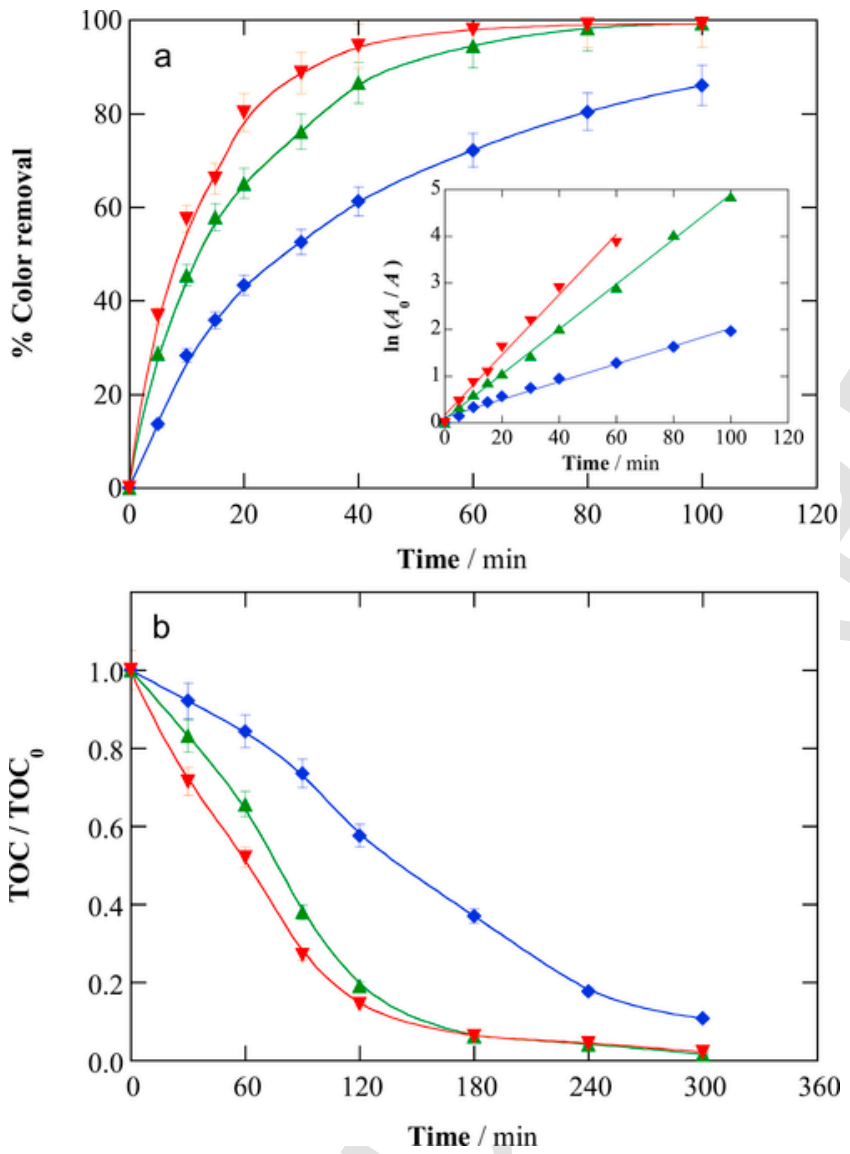

Fig. 4. Influence of current density on (a) percentage of color removal and (b) normalized TOC decay vs. electrolysis time for the SPEF degradation of $2.5 \mathrm{~L}$ of a $0.136 \mathrm{mM}$ Tartrazine $+0.154 \mathrm{mM}$ Pounceau SS $\mathrm{mM}+0.080 \mathrm{mM}$ Direct Blue 71 mixture with $0.050 \mathrm{M} \mathrm{Na} 2 \mathrm{SO} 4$ and $0.50 \mathrm{mM} \mathrm{Fe} 2+$ at $\mathrm{pH} 3.0$ and $35^{\circ} \mathrm{C}$ using a solar pre-pilot flow

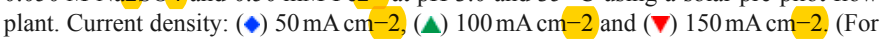
interpretation of the references to color in this figure legend, the reader is referred to the Web version of this article.) $j=150 \mathrm{~mA} \mathrm{~cm}^{-2}$ as compared to that found at $j=50 \mathrm{~mA} \mathrm{~cm}^{-2}$ (see Table 1). Fig. $4 \mathrm{~b}$ highlights the smaller mineralization achieved at the latter $j$, with $89.2 \%$ in $300 \mathrm{~min}$, compared to the similar TOC reduction obtained at the other two $j$ values that yielded total mineralization $(\sim 99 \%$ TOC removal). Fig. SM-3a illustrates the opposite trend for the corresponding MCE profiles, where this parameter decreases clearly with raising $j$ at times longer than $120 \mathrm{~min}$. Table 1 shows that, at $300 \mathrm{~min}$ of electrolysis, the current efficiency decayed largely from $42.1 \%$ to $15.4 \%$ when $j$ increased from 50 to $150 \mathrm{~mA} \mathrm{~cm}^{-2}$. This behavior is characteristic of the EAOPs because of the greater enhancement of non-oxidizing events. Parasitic reactions involve $\mathrm{Pt}\left({ }^{\circ} \mathrm{OH}\right)$ and ${ }^{\circ} \mathrm{OH}$, as for example in the conversion of the former to $\mathrm{O}_{2}$ by reaction (13), and either the dimerization of the latter or its reaction with $\mathrm{H}_{2} \mathrm{O}_{2}$ via reactions (14) and (15), respectively (Brillas et al., 2009; Panizza and Cerisola, 2009; Sirés et al., 2014). The partial consumption of both hydroxyl radicals diminishes their reactivity with organics, ending in lower MCE values.

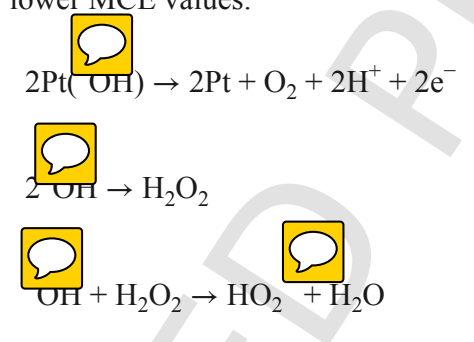

A greater specific energy consumption was calculated at increasing $j$, as seen in Fig. SM-3b and Table 1, because of the concomitant rise of $E_{\text {cell }}$ in $9.9,17.1$ and $23.0 \mathrm{~V}$ for 50,100 and $150 \mathrm{~mA} \mathrm{~cm}^{-2}$. The lowest $j=50 \mathrm{~mA} \mathrm{~cm}^{-2}$ yielded the lowest $\mathrm{EC}_{\mathrm{TOC}}$ values, varying between 0.18 and $0.24 \mathrm{kWh}(\mathrm{g} \mathrm{TOC})^{-1}$. At $j$ values of 100 and $150 \mathrm{~mA} \mathrm{~cm}^{-2}$, $\mathrm{EC}_{\mathrm{TOC}}$ rose gradually from $120 \mathrm{~min}$ of electrolysis, attaining up to $0.66 \mathrm{kWh}(\mathrm{g} \mathrm{TOC})^{-1}$ and as much as $1.34 \mathrm{kWh}(\mathrm{g} \mathrm{TOC})^{-1}$, respectively. Although the use of $j=50 \mathrm{~mA} \mathrm{~cm}^{-2}$ was more cost-effective, $j=100 \mathrm{~mA} \mathrm{~cm}^{-2}$ was preferable for the SPEF treatment of the azo dye mixture because it allows achieving its overall mineralization.

Mixtures with 52, 105 and $157 \mathrm{mgL}^{-1} \mathrm{TOC}$, coming from equal relative molar concentrations of the three azo dyes at $\mathrm{pH} 3.0$, were prepared to examine the effect of the organic load over the SPEF performance at optimum values of $0.50 \mathrm{mM} \mathrm{Fe}^{2+}$ and $j=100 \mathrm{~mA} \mathrm{~cm}^{-2}$. As can be seen in Fig. 5a, the percentage of color removal at a given time decreased at higher initial solution TOC, attaining total decolorization in $80 \mathrm{~min}$ at $52 \mathrm{mg} \mathrm{L}^{-1}$ TOC and 100 min at $105 \mathrm{mg} \mathrm{L}^{-1} \mathrm{TOC}$, whereas at that time only $93.8 \%$ of color was removed using the solution with $157 \mathrm{mg} \mathrm{L}^{-1}$. The inset of this figure confirms again this trend, with a gradual drop of the $k_{\mathrm{dec}}$-value from 0.079 to $0.029 \mathrm{~min}^{-1}$ at increasing TOC contents from 52 to $157 \mathrm{mgL}^{-1}$ (see Table 1). This behavior means that the decolorization rate did not follow a true pseudo-first-order kinetics, i.e., independence from dye concentration as reflected by a constant $k_{\mathrm{dec}}$-value. A different quasi-steady content of $\mathrm{Pt}(\mathrm{OH})$ and $\mathrm{OH}$, modulated by the rate of non-oxidizing reactions and the degradation of oxidation products, was then achieved for each organic load tested. In agreement with this behavior, lower normalized TOC abatement can be observed in Fig. 5b at higher organic load. This can be ascribed to the treatment of larger quantities of organic matter with a similar quantity of hydroxyl radicals formed under the same conditions. Total mineralization was then feasible for azo dye mixtures only up to $105 \mathrm{mg} \mathrm{L}^{-1} \mathrm{TOC}$, reaching a partial mineralization close to $90 \%$ at $157 \mathrm{mgL}^{-1}$. Conversely, Fig. 6a evidences a greater MCE as the initial TOC was increased because of the deceleration of parasitic reactions of $\mathrm{Pt}\left({ }^{\circ} \mathrm{OH}\right)$ and ${ }^{\circ} \mathrm{OH}$, en- 

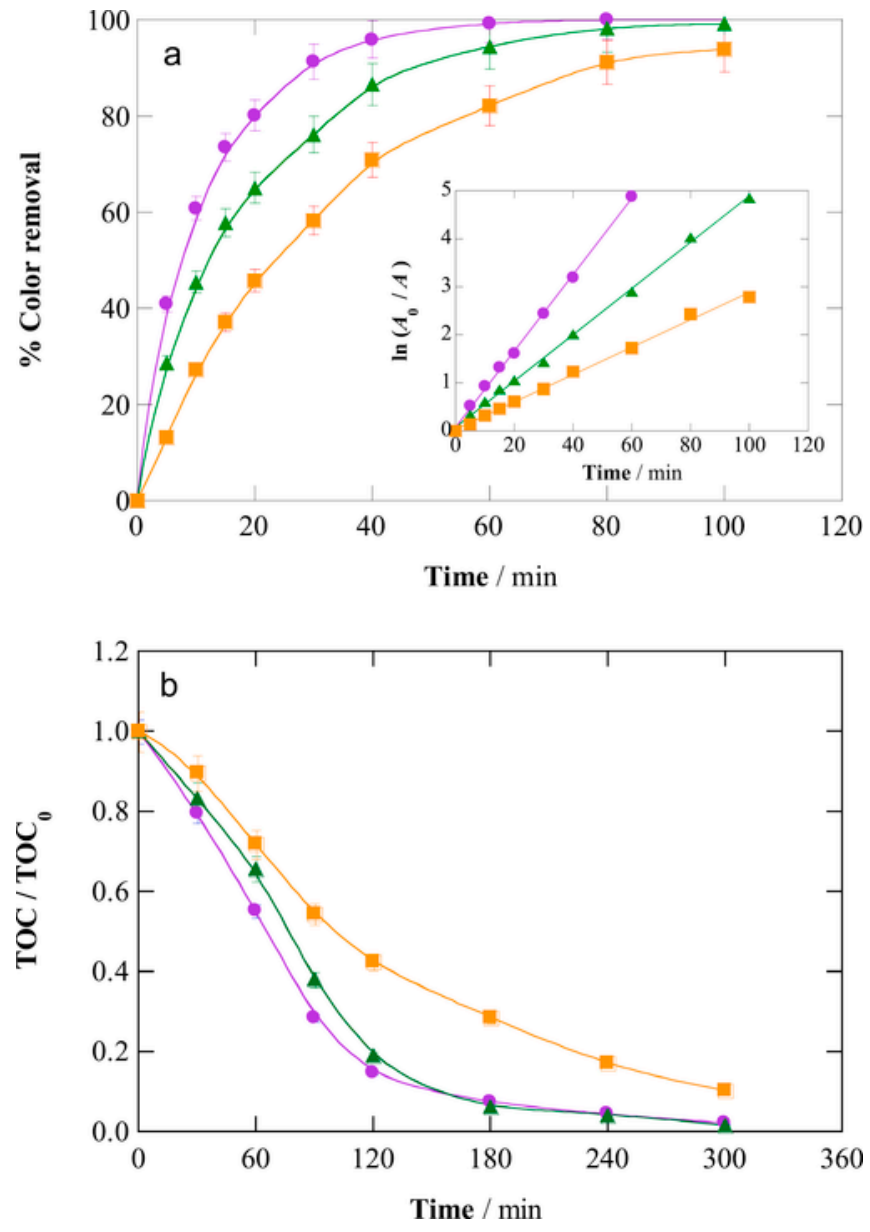

Fig. 5. Effect of azo dye concentration on (a) percentage of color removal and (b) normalized TOC abatement with electrolysis time for the SPEF treatment of $2.5 \mathrm{~L}$ of mixtures with equal relative molar concentration of each azo dye, also containing $0.050 \mathrm{M}$ $\mathrm{Na} 2 \mathrm{SO} 4$ and $0.50 \mathrm{mM} \mathrm{Fe} 2+$, at $\mathrm{pH} 3.0$ and $35^{\circ} \mathrm{C}$ using a solar pre-pilot flow plant at $\mathrm{j}=100 \mathrm{~mA} \mathrm{~cm}-2$. TOC content: (C) $52 \mathrm{mg} \mathrm{L}-1$ (வ) $105 \mathrm{mg} \mathrm{L}-1$ and ( $\square) 157 \mathrm{mg} \mathrm{L}-1$. (For interpretation of the references to color in this figure legend, the reader is referred to the Web version of this article.)

hancing their attack over organics, whereas Fig. 6b illustrates the opposite trend for $\mathrm{EC}_{\mathrm{TOC}}$. These tendencies can also be deduced from the data of Table 1 . Thus, the highest MCE of $31.7 \%$ and the smallest $\mathrm{EC}_{\mathrm{TOC}}$ of $0.48 \mathrm{kWh}(\mathrm{g} \mathrm{TOC})^{-1}$ were found at the highest $157 \mathrm{mg} \mathrm{L}^{-1}$ TOC.

\section{Conclusions}

Solutions containing $0.136 \mathrm{mM}$ Tartrazine $+0.154 \mathrm{mM}$ Ponceau $\mathrm{SS}+0.080 \mathrm{mM}$ Direct Blue $71\left(105 \mathrm{mg} \mathrm{L}^{-1} \mathrm{TOC}\right)$ at $\mathrm{pH} 3.0$ can be totally decolorized in $100 \mathrm{~min}$ and mineralized in $300 \mathrm{~min}$ by SPEF in a flow plant, with $0.50 \mathrm{mM} \mathrm{Fe}^{2+}$ and $j=100 \mathrm{~mA} \mathrm{~cm}^{-2}$ as optimum parameters. The percentages of color and mineralization removals were very small using $\mathrm{AO}-\mathrm{H}_{2} \mathrm{O}_{2}$, demonstrating the low oxidation power of $\mathrm{Pt}(\mathrm{OH})$. The decolorization rate in EF was similar to that found in SPEF because the main oxidant was $\mathrm{OH}$ originated from Fenton's reaction (3) in both cases. However, SPEF gave much larger mineralization due to the complete photodecomposition of photoactive by-products under sunlight irradiation. This has been directly related to the formation of eight linear carboxylic acids. Initial $\mathrm{S}$ and $\mathrm{N}$ contained in the azo dyes were mainly transformed into $\mathrm{SO}_{4}{ }^{2-}$ and $\mathrm{NH}_{4}^{+}$ions. The absorbance decay always obeyed a pseudo-first-order

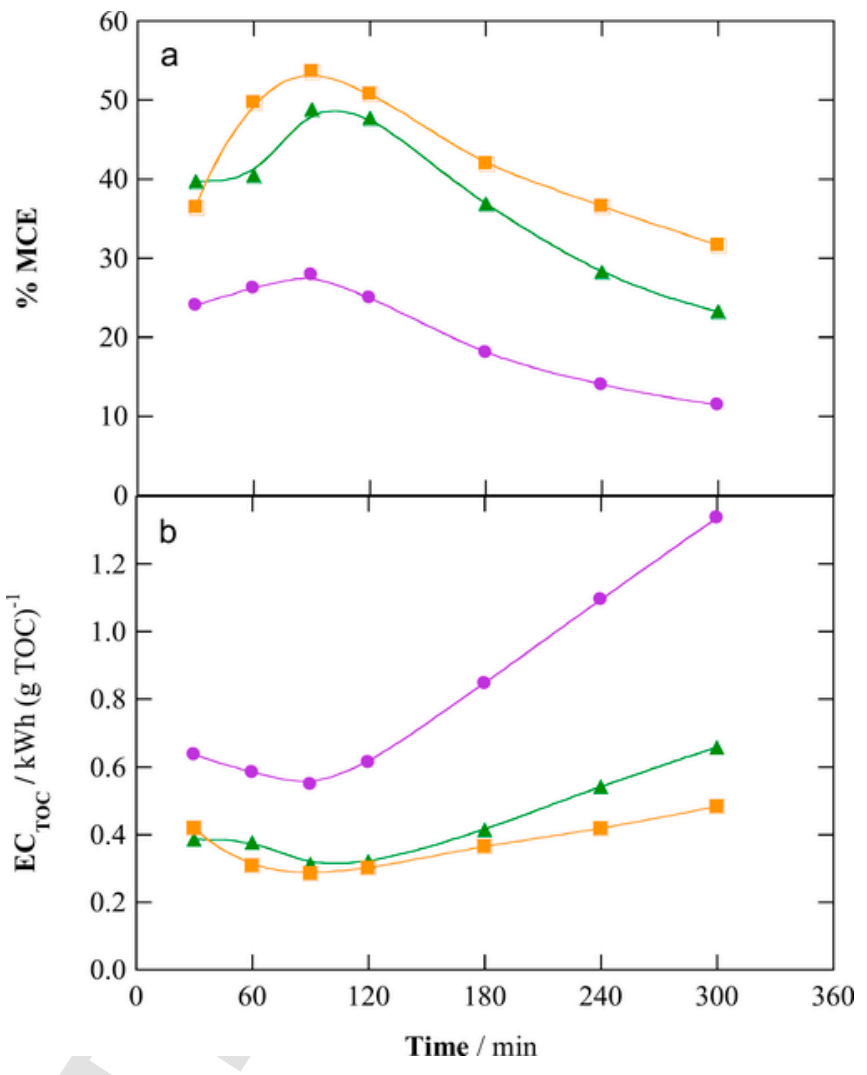

Fig. 6. Time course of (a) mineralization current efficiency and (b) specific energy consumption per unit TOC mass for the assays of Fig. 5b.

kinetics. Decrease of $j$ and increase of initial TOC led to the greatest $\mathrm{MCE}$ and lowest $\mathrm{EC}_{\mathrm{TOC}}$ values.

\section{Acknowledgements}

Financial support from project CTQ2016-78616-R (AEI/FEDER, EU) and projects CNPq - 465571/2014-0; CNPq - 446846/2014-7 and $\mathrm{CNPq}$ - 401519/2014-7T (National Council for Scientific and Technological Development, Brazil) is acknowledged. A.J. dos Santos is also grateful to the doctoral grant awarded from CAPES and "doutorado sanduíche" scholarship under the Program PDSE-CAPES (88881.133501/2016-01).

\section{Appendix A. Supplementary data}

Supplementary data related to this article can be found at https:// doi.org/10.1016/j.chemosphere.2018.07.116.

\section{Uncited reference}

Pokharna and Shrivastava, 2013.

\section{References}

Anjaneyulu, Y., Chary, N.S., Raj, S.S., 2005. Decolourization of industrial effluents available methods and emerging technologies - a review. Rev. Environ. Sci. Biotechnol. 4, 245-273.

Bezerra Rocha, J.H., Sales Solano, A.M., Fernandes, N.S., Ribeiro da Silva, D., Peralta-Hernández, J.M., Martínez-Huitle, C.,A., 2012. Electrochemical degradation of Remazol Red BR and Novacron Blue C-D dyes using diamond electrode. Electrocatalysis $3,1-12$. 
Bhattacharya, B., Sanghi, R., 2003. Adsorption-coagulation for the decolorisation of textile dye solutions. Water Qual. Res. J. Can. 38, 553-562.

Brillas, E., Martínez-Huitle, C.A., 2015. Decontamination of wastewaters containing synthetic organic dyes by electrochemical methods. An updated review. Appl. Catal. B: Environ. 166-167, 603-643.

Brillas, E., Sirés, I., Oturan, M.A., 2009. Electro-Fenton and related electrochemical technologies based on Fenton's reaction chemistry. Chem. Rev. 109, 6570-6631

Chaiyont, R., Badoe, C., Ponce de León, C., Nava, J.L., Recio, F.J., Sirés, I., Herrasti, P., Walsh, F.C., 2013. Decolorization of methyl orange dye at $\mathrm{IrO}_{2}-\mathrm{SnO}_{2}-\mathrm{Sb}_{2} \mathrm{O}_{5}$ coated titanium anodes. Chem. Eng. Technol. 36, 123-129.

Coria, G., Pérez, T., Sirés, I., Brillas, E., Nava, J.L., 2018. Abatement of the antibiotic levofloxacin in a solar photoelectron-Fenton flow plant: modeling the dissolved organic carbon concentration-time relationship. Chemosphere 198, 174-181.

Coria, G., Pérez, T., Sirés, I., Nava, J.L., 2015. Mass transport studies during dissolved oxygen reduction to hydrogen peroxide in a filter-press electrolyzer using graphite felt, reticulated vitreous carbon and boron-doped diamond as cathodes. J. Electroanal. Chem. 757, 225-229.

Cruz-Rizo, A., Gutiérrez-Granados, S., Salazar, R., Peralta-Hernández, J.M., 2017. Application of electro-Fenton/BDD process for treating tannery wastewaters with industrial dyes. Separ. Purif. Technol. 172, 296-302.

Dirany, A., Sirés, I., Oturan, N., Özcan, A., Oturan, M.A., 2012. Electrochemical treatment of the antibiotic sulfachloropyridazine: kinetics, reaction pathways, and toxicity evolution. Environ. Sci. Technol. 46, 4074-4082.

dos Santos, A.B., Cervantes, F.J., van Lier, J.B., 2007. Review paper on current technologies for decolourisation of textile wastewaters: perspectives for anaerobic biotechnology. Bioresour. Technol. 98, 2369-2385.

dos Santos, A.J., de Lima, M.D., da Silva, D.R., Garcia-Segura, S., Martínez-Huitle, C.A., 2016. Influence of the water hardness on the performance of electro-Fenton approach: decolorization and mineralization of Eriochrome Black T. Electrochim. Acta 208, 156-163.

dos Santos, A.J., Martínez-Huitle, C.A., Sirés, I., Brillas, E., 2018. Use of Pt and BDD anodes in the electrochemical advanced oxidation of Ponceau SS diazo dye in acidic sulfate medium. ChemElectroChem 5, 685-693.

El-Ghenymy, A., Rodríguez, R.M., Brillas, E., Oturan, N., Oturan, M.A., 2014. Electro-Fenton degradation of the antibiotic sulfanilamide with Pt/carbon-felt and $\mathrm{BDD} /$ carbon-felt cells. Kinetics, reaction intermediates, and toxicity assessment. Environ. Sci. Pollut. Res. 21, 8368-8378.

Ellouze, S., Kessemtini, S., Clematis, D., Cerisola, G., Panizza, M., Chaâbane Elaoud, S., 2017. Application of Doehlert design to the electro-Fenton treatment of Bismarck Brown Y. J. Electroanal. Chem. 799, 34-39.

Flox, C., Garrido, J.A., Rodríguez, R.M., Cabot, P.L., Centellas, F., Arias, C., Brillas, E., 2007. Mineralization of herbicide mecoprop by photoelectro-Fenton with UVA and solar light. Catal. Today 129, 29-36.

Forgacs, E., Cserháti, T., Oros, G., 2004. Removal of synthetic dyes from wastewaters: a review. Environ. Int. 30, 953-971.

Galia, A., Lanzalaco, S., Sabatino, M.A., Dispenza, C., Scialdone, O., Sirés, I., 2016. Crosslinking of poly(vinylpyrrolidone) activated by electrogenerated hydroxyl radicals: a first step towards a simple and cheap synthetic route of nanogel vectors. Electrochem. Commun. 62, 64-68.

Garcia-Segura, S., Brillas, E., 2016. Combustion of textile monoazo, diazo and triazo dyes by solar photoelectro-Fenton: decolorization, kinetics and degradation routes Appl. Catal. B Environ. 181, 681-691.

Ghoneim, M.M., El-Desoky, H.S., Zidan, N.M., 2011. Electro-Fenton oxidation of Sunset Yellow FCF azo-dye in aqueous solutions. Desalination 274, 22-30.

Khandegar, V., Saroha, A.K., 2013. Electrocoagulation for the treatment of textile industry effluent-a review. J. Environ. Manag. 128, 949-963.

Moreira, F.C., Boaventura, R.A.R.. Brillas, E., Vilar, V.J.P., 2017. Electrochemical advanced oxidation processe view on their application to synthetic and real wastewaters. Appl. Catal. 2 iron. 202, 217-261.

Murillo-Sierra, J.C., Sirés, I., Brillas, E., Ruiz-Ruiz, E.J., Hernández-Ramírez, A., 2018. Advanced oxidation of real sulfamethoxazole + trimethoprim formulations using different anodes and electrolytes. Chemosphere 192, 225-233.

Olvera-Vargas, H., Oturan, N., Oturan, M.A., Brillas, E., 2015. Electro-Fenton and solar photoelectro-Fenton treatments of the pharmaceutical ranitidine in pre-pilot flow plant scale. Separ. Purif. Technol. 146, 127-135.
Oturan, M.A., Aaron, J.J., 2014. Advanced oxidation processes in water/wastewater treatment: Principles and applications. A review. Crit. Rev. Environ. Sci. Technol. 44, 2577-2641.

Panizza, M., Cerisola, G., 2009. Direct and mediated anodic oxidation of organic pollutants. Chem. Rev. 109, 6541-6569.

Pérez, T., Sirés, I., Brillas, E., Nava, J.L., 2017. Solar photoelectro-Fenton flow plant modeling for the degradation of the antibiotic erythromycin in sulfate medium. Electrochim. Acta 228, 45-56.

Pokharna, S., Shrivastava, R., 2013. Photocatalytic treatment of textile industry effluent using titanium oxide. Int. J. Recent Res. Rev. VI, 9-17.

Rajkumar, D., Kim, J.G., 2006. Oxidation of various reactive dyes with in situ electro$\mathrm{g} C \mathrm{~d}$ active chlorine for textile dyeing industry wastewater treatment. J. Hazar r. B136, 203-212.

Robinson, T., McMullan, G., Marchant, R., Nigam, P., 2001. Remediation of dyes in textile effluer a itical review on current treatment technologies with a proposed alternative. B 2 hnol. 77, 247-255.

Ruiz, E.J., Hernández-Ramírez, A., Peralta-Hernández, J.M., Arias, C., Brillas, E., 2011. Application of solar photoelectro-fenton technology to azo dyes mineralization: effect of current density, $\mathrm{Fe}^{2+}$ and dye concentration. Chem. Eng. J. 171, 385-392.

Salazar, R., Brillas, E., Sirés, I., 2012. Finding the best $\mathrm{Fe}^{2+} / \mathrm{Cu}^{2+}$ combination for the solar photoelectro-Fenton treatment of simula stewater containing the industrial textile dye Disperse Blue 3. Appl. Catal. 2 iron. 115-116, 107-116.

Santos, V., Morão, A., Pacheco, M.J., Ciríaco, L., Lopes, A., 2008 Electrochemical degradation of azo dyes on BDD: effect of chemical struct ead operating conditions on the combustion efficiency. J. Environ. Eng. Mana 193-204.

Sharma, K.P., Sharma, S., Sharma, S.P., Singh, K., Kumar, S., Grover, R., Sharma, P.K., 2007. A comparative study on characterization of textile wastewaters (untreated and treated) toxicity by chemical and biological tests. Chemosphere 69 , $48-54$.

Sirés, I., Brillas, E., Oturan, M.A., Rodrigo, M.A., Panizza, M., 2014. Electrochemical advanced oxidation processes: today and tomorrow. A review. Environ. Sci. Pollut. Res. 21, 8336-8367.

Solano, A.M.S., Garcia-Segura, S., Martínez-Huitle, C.A., Brillas, E., 2015. Degradation of acidic aqueous solutions of the diazo dye Congo Red by photo-assisted electrochemical processes based on Fenton's reaction chemistry. Appl. Catal. 2 Environ. 168-169, 559-571.

Solís, M., Solís, A., Pérez, H.I., Manjarrez, N., Flores, M., 2012. Microbial decolouration of azo dyes: a review. Process Biochem. 47, 1723-1748.

Steter, J.R., Brillas, E., Sirés, I., 2018. Solar photoelectro-Fenton treatment of a mixture of parabens spik secondary treated wastewater effluent at low input current. Appl. Catal. 2 iron. 224, 410-418.

Thiam, A., Sirés, I., Brillas, E., 2015a. Treatment of a mixture of food color additives (E122, E124 and E129) in different water matrices by UVA and solar photoelectro-Fenton. Water Res. 81, 178-187.

Thiam, A., Sirés, I., Centellas, F., Cabot, P.L., Brillas, E., 2015b. Decolorization and mineralization of Allura Red AC azo dye by solar photoelectro-Fenton: identification of intermediates. Chemosphere 136, 1-8.

Ulson de Souza, S.M.A.G., Forgiarini, E., Ulson de Souza, A.A., 2007. Toxicity of textile and their degradation by the enzyme horseradish peroxidase (HRP). J. Hazar 2 r. 147, 1073-1078.

UNESCO, 2012. The United Nations World Water Development Report 4, Volume 1: Managing Water Report under Uncertainty and Risk.

Verma, A.K. Dash, R.R., Bhunia, P., 2012. A review on chemical coagulation/flocculatio ecelogies for removal of colour from textile wastewaters. J. Environ. Man 2 154-168.

Vilar, V.J.P., Pinho, L.X., Pintor, A.M.A., Boaventura, R.A.R., 2011. Treatment of textile wastewaters by solar-driven advanced oxidation processes. Sol. Energy 85, 1927-1934.

Zollinger, H., 2003. Color Chemistry: Synthesis, Properties, and Applications of Organic Dyes and Pigments. VHCA and Wiley-VCH, Switzerland. 